\title{
Does Spain Really Need a Foreign Policy Strategy? More than a Proposal from a Think Tank
}

\author{
Laia MESTRES*
}

\begin{abstract}
In March 20I4, the Elcano Royal Institute presented the Report "Towards the Strategic Renewal of Spain's Foreign Policy", whose aim was to provide general guidelines and some specific suggestions for a Spanish long-term strategy on external action. This Report was a direct demand from the Spanish government to this think tank as a previous step to work on the first-ever External Action Strategy. The Elcano Royal Institute brought together more than 200 experts from different fields (Public Administration, University and Think Tanks, Business, Parliament) to make an in-depth reflection on the future of Spanish foreign policy and on how Spain can become a more strategic actor in this ever-changing globalized world.
\end{abstract}

Keywords: Spain's Foreign Policy - Think Tank - External Action Strategy - Ministry of Foreign Affairs and Cooperation

\section{INTRODUCTION}

In March 20I4, the Elcano Royal Institute presented the Report "Towards the Strategic Renewal of Spain's Foreign Policy", whose aim was to provide general guidelines and some specific suggestions for a Spanish long-term strategy on external action. This was not the first time that a broad proposal for the future of Spanish foreign policy came from the think tank world or academia. ${ }^{2}$ On this occasion the novelty was basically that it was a direct demand from the Spanish government to this think tank as a previous step to work on the first-ever External Action Strategy.

Established in 200I, the Elcano Royal Institute is probably the Spanish think-tank for international relations closer to the government. So, it was not a surprise that this think tank assumed the impressive task to advise the Ministry of Foreign Affairs and Cooperation in drafting a comprehensive and long-term approach to foreign policy. "Essentially, think tanks seek to bridge the gap between knowledge and power". In this case, the Elcano Royal Institute brought together more

\footnotetext{
Postdoctoral Researcher at Institut Barcelona d'Estudis Internacionals (IBEI) and member of the Observatory of European Foreign Policy. Imestres@ibei.org.

I. Molina (coord.), Hacia una renovación estratégica de la política exterior española and Executive Summary and Conclusions of the Elcano Report "Towards the Strategic Renewal of Spain's Foreign Policy", Informe Elcano Is (Madrid, Real Instituto Elcano, 20I4), available electronically at (http://www.realinstitutoelcano.org/wps/portal/web/rielcano_es/ publicacion?WCM_GLOBAL_CONTEXT=/elcano/elcano_es/publicaciones/informe-elcano-I5-renovacion-politicaexterior-espana).

2 For instance: J. I. Torreblanca, 'Una auditoria democrática de la política exterior' in J. Estefanía (dir.), Informe sobre la Democracia en España 2010 (Madrid, Fundación Alternativas, 2010) 163-186; R. Youngs, Cómo potenciar la política exterior española (Madrid, FRIDE, 2010); J. M. Beneyto and J. C. Pereira (dirs.), Politica exterior española: Un balance de futuro (Madrid, Biblioteca Nueva, 20II); J. Vaquer, 'Un lugar para España tras la crisis', I4I, Política Exterior (May/June 20II), 7889; I. Molina, 'El futuro de España en el mundo', I40, Nueva Revista de Política, Cultura y Arte (2012), 23-36.

J. G. McGann and E.C. Johnson, Comparative Think Tanks, Politics, and Public Policy (Edward Elgar, Cheltenham and Northampton, 2005), at I2.
} 
than 200 experts from different fields (Public Administration, University and Think Tanks, Business, Parliament) to make an in-depth reflection on the future of Spanish foreign policy and on how Spain can become a more strategic actor in this ever-changing globalized world.

Francisco de Borja Lasheras and José Ignacio Torreblanca, from the Madrid office of the European Council on Foreign Relations (ECFR), had denounced that when the economic situation was buoyant, Spain was prone to take action but planned shortly. In other words, there was no interest in prioritizing because there were enough resources to achieve all the goals set. ${ }^{4}$ Indeed, Spain has suffered from a lack of long-term planning in foreign policy as well as has never followed a proper democratic accountability process in this area. Traditionally foreign policy guidelines of each government were only orally presented by the Minister of Foreign Affairs and Cooperation to the Parliament at the beginning of each term. It is never too late to change such dynamics in foreign policy. This chronicle will critically summarize the main points of Elcano's contribution to strategically renew Spain's foreign policy, will transcribe the Report's conclusions and finally will conclude with some thoughts on this step towards the first Spain's External Action Strategy.

\section{A PROPOSAL OF STRATEGIC RENEWAL OF SPAIN'S FOREIGN POLICY}

The Elcano Report follows the traditional structure of this kind of policy-oriented essays. It starts by looking at Spain's fundamental values and interests while analyzing the risks and opportunities for the country's international role. It then explores the what, where and how of the Spanish external action; that is to say, the strategic objectives to be pursued, the geographical areas of action, and the means and instruments available for this concrete policy. Finally, it closes with a series of recommendations about the renewal of Spain's foreign policy in order to place again the country in the world as a medium-sized power with a global presence.

\section{(I) Strategic Objectives}

To start with, the Elcano team, coordinated by Ignacio Molina, developed a SWOT analysis to evaluate the strengths, weaknesses, opportunities and threats involved in the evolution of Spain as an influential actor in the international arena. Apart from the evident impact of the economic crisis on Spain's global presence causing a record high on the unemployment rate but also a reduction of investment in education or research and development, factors such as the ageing population, the growing distrust in politics or the external energy dependence are some of the weaknesses highlighted in this Report. Although culture, people's solidarity or even geopolitical situation can be part of Spain's soft power, the country has been unable to make better use of it. As far as strengths and opportunities are concerned, Spain has at its disposal a high level of socioeconomic development, a certain political-institutional stability, sound external projection in the business world, not to mention the asset of Spanish as a global language and a close relationship with Latin America.

F. Lasheras and J.I. Torreblanca, 'España: irepliegue estratégico en su política exterior?', 158, Política Exterior, (February/March 2014), 16-24, at 16. 
The Report identified “six strategic objectives, three of which relate[d] to fulfilling Spain's own domestic aspirations (democracy, security, and competitiveness and talent) while the other three [were] more connected to foreign policy (European integration, international responsibility and influence)." This chronicle will focus only on the foreign policy strategic objectives. The first priority was, without any doubt, the strengthening of European integration, maintaining internal cohesion and regaining legitimacy from European citizens. The Report firmly suggested that Spain, as the fifthlargest member state, must be more active in developing, "its own narrative on the type of federalizing integration that best suits it and take a more proactive role, generating its own ideas on the construction of Europe as a whole and on the various common policies". The authors even dared to obviously call this federal proposal as the 'United States of Europe'. Many analysts explained that due to the crisis Spain's inward-looking attitude had returned the country to the periphery of Europe. Among them, Ignacio Molina had explained in 2013 that the causes for Spain's irrelevance within the European Union (EU) were not only due to the economic crisis but mainly to a clear process of deEuropeanization. Shortly said, Spain turned out to be more a matter of concern for the EU than an actor shaping European policies. In order to overcome this passive attitude, the Elcano team recommended in the Report that the government should better define the nation's position in each European issue but above all work together with the European institutions and other largest member states to be more influential on the future of the EU.

Defined as international responsibility, the second foreign policy goal was meant to seek Spain's greater contribution to the protection of human rights, development cooperation, humanitarian aid and the generation of global public goods -especially in the fight against climate change. In accordance with the report, this goal would only be achieved if the government provided appropriate means to its external action such as qualified human resources, a reversal of the decline in the budget for development cooperation, and a greater and sectorial concentration of this aid. In fact, in a previous Elcano report evaluating the first roo days of Rajoy's government in February 20I2, this think tank had already suggested the need to better plan the development policies following strictly the principles of transparency, efficacy and effectiveness. ${ }^{6}$

The third goal of this wide range of strategic objectives was influence, also known as soft power. Apart from being more active in the regional and international organizations of which Spain is member, influence can also come from non-state actors such as migrants, companies or even tourists and students. In this sense, the Report made a point that the international image that Spain can project externally has to be based on democratic values, excellent education and business environment, environmental commitment and cultural diversity.

\section{(2) Geographical Areas}

Traditionally, Spanish foreign policy has been described as a triangle whose superior vertex is the policy towards Europe and the other two are the policies towards the Mediterranean and Latin

I. Molina, 'Una nueva política europea después de tocar fondo', 152, Política Exterior, (March/April 2013), 84-96, at 87.

I. Molina, I. Olivé and F. Steinberg, 'La reorganización de la acción exterior española por el nuevo gobierno del Partido Popular', 9, Análisis del Real Instituto Elcano, (16/02/2012), at 9. 
America, respectively, since both are important regions but definitely come second to Europe. ${ }^{7}$ The geographical areas identified in the Report map the whole world, not only these three traditional areas of interests: "Europe; the Maghreb and all of Europe's southern neighborhood; Latin America; the US and the North Atlantic; Asia-Pacific; and the global sphere itself'. But not only the Report put the focus on the regional dimension, it also highlighted the importance of bilateral relations for Spain's foreign policy (with the largest EU member states, but also Portugal, the Maghreb countries, Turkey, China, the US and even Cuba). It provided a full detailed agenda about which priorities have to be developed with each country.

As far as the superior vertex is concerned, the never-ending debate in Europe has been the evolution towards a variable geometry within the EU where some countries go further in the integration while others do not, even if they are already EU member states. Spaniards have been generally fearful of this proposal of two-speed Europe, since this would probably imply that Spain would no longer be included in the central core of the process of European integration. But the fact is that in the last thirty years Madrid has always taken part in any project of variable geometry (WEU, Schengen, Euro). Despite this, the growing feeling of returning to the periphery of Europe was seen by the authors as a sign of the need to strongly recommend Madrid to fight against the consolidation of political and economic cleavages between creditor and debtor countries.

Concerning the two inferior vertices, Charles Powell, Director of the Elcano Royal Institute, recognized in 2012 that, even before the economic crisis, Spain was already experiencing difficulties in Latin America and the Mediterranean regions, the two historical non-European areas of greatest importance for the country. ${ }^{8}$ The Report stated that the Spanish priority for North Africa must be to transform the region from a border to a geopolitical space of its own, which it will only be possible with strengthening the EU support. In particular, Spain must continue enhancing the Southern dimension of the European Neighbourhood Policy and supporting the political liberalization of these countries. As Eduard Soler i Lecha and Jordi Vaquer warned some years ago, "better results can be obtained by pushing the EU to be active rather than by pursuing a regional policy based on national interests". ${ }^{9}$ Regarding Latin America (a notion preferred to Ibero-America), the Report focused on the need to appeal the Spanish leadership in the region before the EU, and even the US. However, the diplomatic instruments have to be updated. Concretely, "the Ibero-American Summits need to be rethought, preserving their 'family diplomacy' character, mainly aimed at promoting cooperation in all spheres on the sound basis of a close-knit and active network that unites the civil societies on both sides of the Atlantic". Furthermore, bilateral relations established by Spain with some Latin American countries must be rethought in order to develop a distinct agenda of cooperation based on strategic criteria but also to foster a Brazilian-Spanish alliance.

E. Barbé, 'Spain and CFSP: The Emergence of a "Major Player"?', in R. Gillespie and R. Youngs (eds.), Spain: The European and International Challenges (Frank Cass, London and Portland, 200I) at $5 \mathrm{I}$.

8 C. Powell, 'The Pain in Spain: Political, Social and Foreign Policy Implications of the European Economic Crisis' Análisis del Real Instituto Elcano, (31/12/2012), at I2.

9 E. Soler i Lecha and J. Vaquer i Fanés, 'The Mediterranean in the EU's Spanish Presidency: A Priority in Turbulent Times', 15: I, Mediterranean Politics (2010), 73-79, at 73. 
Finally, Spain's relations with the other regions, named as North Atlantic and Asia-Pacific regions, will also have a sense of priority but always through the lenses of the European Union. On the one hand, the Report simply pointed out that Spain fully supports the completion of the Transatlantic Trade and Investment Partnership between the EU and the US, but showing that the country must pay particular attention to its potential impact on Latin America. On the other, apart from supporting EU's Asian policy, the Elcano team recommended Spain to develop its own approach towards China. The less dependent on economic trade and investment the Spanish relations with China, the more potential there is for a closer political relationship. This section of the Report ended with a reference to the provision of public goods and the establishment of legitimate and effective rules of governance. Even though Spain's capacity to impose its interests is limited, it can make a specific contribution on issues such as financial stability, trade regulation, poverty reduction, or fight against climate change.

\section{(3) Instruments and Actors}

The proposal for restructuring means and instruments developed in the Report was not particularly original. Nevertheless, due to the fact that Spain's foreign policy has practically not updated its diplomatic methods and procedures, their proposal seemed to be more timely than ever. Taking into account that foreign policy cannot solely be developed by the Ministry, it is crucial to identify inputs by different government's departments and also from the EU, the autonomous communities and the private sector (companies and NGOs). The six instruments identified in the Report offered a comprehensive and integrated picture of external action: diplomacy; consular protection and assistance; security, defence and intelligence; economy and business promotion; development cooperation; and, cultural and education-scientific action. In addition, the Report made a logical proposal for a new procedural system based on six phases to carry out the making of foreign policy: planning, external consultation, decision-making, implementation, evaluation and accountability.

What is indeed interesting from this part of the paper related to instruments and processes was the proposal of internal reorganization of the government in order to integrate rather than coordinate the external action of the country. This would ensure the direct participation of all actors in the process and facilitate convergence. The proposal was as follows:

"The integration of external action should be based on three equally important organizational mechanisms: the Prime Minister, a collegiate political council and the Ministry of Foreign Affairs and Cooperation. The Prime Minister, who in Spain has the major responsibility for political direction, does not currently have a system to enable him[/her] to exercise effective strategic leadership over the country's external action, either when collectively presiding over all the departments involved or in his[her]personal field of action that, moreover, includes taking all major critical decisions. The function of the political council, which needs the appropriate but flexible and streamlined technical support, is to provide a political meeting place for those involved in Spain's external action. For its part, the Ministry of Foreign Affairs and Cooperation must reformulate its geographical approach and, especially, reinforce its currently thematic approach. The idea is to have a proper overall view of each 
region and country and to act to as a major catalyst to help integrate all the policies that have an external projection."

This political council on foreign policy would be responsible of drafting the External Action Strategy of the government which would be updated in each four-year term of office. This final proposal comes full circle. The initial goal of the Elcano Report was to provide general guidelines for a long-term strategy on external action which will be officially named as External Action Strategy. Definitely, if Spain wants to become a truly "medium-sized power with a global presence", it has to start thinking about how to be influential in the international arena through changing reality and not only simply reacting before real world events.

\section{THE REPORT'S RECOMMENDATIONS}

Any policy-oriented report must finish with a section of recommendations. And more often than admitted, decision-makers only read these two-page conclusions. Here you have: "The recommendations, in the Elcano Royal Institute's view, constitute the Io foundations on which to base a renewed vision of Spain's place in the world and of the realistic but influential role that it can play as a medium-sized power with a global presence, and as an advanced, responsible and proEuropean democracy that seeks a collective model based on coexistence, security, sustainable prosperity culture and knowledge".

I. "In the service of the public. The strategic renewal of Spanish foreign policy must be guided by the promotion of the public's values and interests. This task must be carried out both within the country's borders - so that the public believe that external action brings them benefits in the fields of democracy, security, sustainable prosperity and knowledge- as well as beyond them, taking into account the growing international presence of Spaniards that require assistance and protection. [...]

2. Better connecting Spain to the World. The priority aim of a strategic foreign policy is to better link the country with its new international environment, which is transforming the daily parameters of welfare and security. [...]

3. Intelligent Europeanism as a basis. To regain its prosperity and maintain its security, Spain needs an internally cohesive and globally active EU. Therefore, the Europeanism of Spain, which is the fifth-largest member state of an EU of almost 30 members, cannot be solely receptive or resigned. As well as loyally fulfilling its obligations as part of the integration process, Spain must be constantly active in driving and shaping it so that the progress made is in accordance with the country's values and interests.

4. Ambitious for its own presence and influence. Spain's substantial and loyal participation in the EU does not mean that it has to give up thinking and acting for itself. This is especially true in areas where it makes sense for it to do so due to the lack of a developed European external action, because the goals to fulfil are its own (the projection of its businesses, ideas or global language) or where the added value of the opportunities and/or risks for its security are particularly strong (Latin America and North Africa). [...] 
5. Co-responsibility in generating global public goods. [...] Promoting international peace, human rights and freedoms, development or the fight against climate change is not only an expression of solidarity or - even less so- a generous luxury, but rather an obligation to which it is duty-bound and which also contributes to improving democracy, security, prosperity and knowledge back home.

6. Based on innovation and talent. Spain can only address globalization through knowledge and added value. [...] This requires rethinking the country's growth model, basing it on improvements in productivity that will come from a more internationalized education, talent attraction, a scientific system better connected to industry, and competitive businesses integrated into global value chains.

7. Projecting a sound and respected image. Spain must present itself as an active international actor with well-defined priorities, one that is capable of generating useful initiatives and that bases its credibility on the legitimacy of its political system and the robustness of its economy, which requires weaknesses in those spheres to be addressed. Spain today is a tolerant, modern, sound, supportive, creative, plural and dependable country with a high quality of life, which respects the environment and values its historical legacy. [...]

8. Through an integrated system of instruments and players. [...] This creates the need for a collective system, one led at the highest level, mediated by the Ministry of Foreign Affairs and Cooperation and with a strong parliamentary involvement. It must be less concerned with controlling than with integrating visions and instruments (diplomatic, consular, security, trade, cultural-scientific and cooperation) in an inclusive approach to the general interest.

9. Equipped with greater intelligence. [...] [Spain] must reinforce its own thinking (both through planning units within the public authorities as well as relying on consultancy services from independent experts) from the phase of governmental planning through to parliamentary accountability. [...]

IO. Taking evaluation seriously. Both the implementation of external action and the results obtained must be followed and measured systematically. [...]"

\section{CONCLUSIONS}

“Towards the Strategic Renewal of Spain's Foreign Policy” was not a mere policy-oriented paper from a think tank. It was meant to be the basis on which the government will build the first External Action Strategy for the next few years. The government submitted in 5 December 2014 its proposal of External Action Strategy to Parliament. It is not the goal of this article to compare the Elcano Report with the government's strategy, but Ignacio Molina recognized in an article published at the journal 
Politica Exterior in January 2015 that the final Strategy elaborated by the Ministry had not really included any of the most innovative recommendations of their Report. ${ }^{\mathrm{IO}}$

It is commonsense among IR experts that foreign policy is not anymore an exclusive domain of any Ministry of Foreign Affairs. There are de facto several actors involved in this area: from international and regional organizations to sub-state entities; from public actors in the government and also in the Parliament to private actors. The Elcano Report was clear on the need for more transparency, accountability and a sense of ownership by the whole of foreign policy actors in a country. In this sense, the process of drafting the Report summarized in this chronicle was an example of these principles.

Does Spain really need now a Foreign Policy (or External Action) Strategy? More than ever. It is a fact that the impact of the harsh economic crisis in Spain also affected its global presence in the international arena. Only through an ambitious strategy to redefine its global goals and alliances, Spain will be able to play again some sort of influential role in the world.

ro I. Molina 'Estrategia de Acción Exterior: Logro, ma non troppo', I63, Política Exterior (January/February 2015), (http://www.politicaexterior.com/articulos/politica-exterior/estrategia-de-accion-exterior-logro-ma-non-troppo/) 